University of Nebraska - Lincoln

DigitalCommons@University of Nebraska - Lincoln

Publications, Agencies and Staff of the U.S.

Department of Commerce

U.S. Department of Commerce

$12-12-1969$

\title{
Blind River Dolphin: First Side-Swimming Cetacean
}

Earl S. Herald

Steinhart Aquarium, California Academy of Sciences, San Francisco

Robert L. Brownell Jr.

Steinhart Aquarium, California Academy of Sciences, San Francisco, rlbcetacea@aol.com

Fredric L. Frye

Steinhart Aquarium, California Academy of Sciences, San Francisco

Elkan J. Morris

Steinhart Aquarium, California Academy of Sciences, San Francisco

William Evans

Naval Undersea Research and Development Center, San Diego, California 92132

See next page for additional authors

Follow this and additional works at: https://digitalcommons.unl.edu/usdeptcommercepub

Part of the Environmental Sciences Commons

Herald, Earl S.; Brownell, Robert L. Jr.; Frye, Fredric L.; Morris, Elkan J.; Evans, William; and Scott, Alan, "Blind River Dolphin: First Side-Swimming Cetacean" (1969). Publications, Agencies and Staff of the U.S. Department of Commerce. 138.

https://digitalcommons.unl.edu/usdeptcommercepub/138

This Article is brought to you for free and open access by the U.S. Department of Commerce at DigitalCommons@University of Nebraska - Lincoln. It has been accepted for inclusion in Publications, Agencies and Staff of the U.S. Department of Commerce by an authorized administrator of DigitalCommons@University of Nebraska - Lincoln. 


\section{Authors}

Earl S. Herald, Robert L. Brownell Jr., Fredric L. Frye, Elkan J. Morris, William Evans, and Alan Scott 


\section{Blind River Dolphin:}

\section{First Side-Swimming Cetacean}

Abstract. The blind river dolphin (Platanista gangetica), first written about by Pliny the Elder in A.D. 72, was found (10 November 1968) to be the first known side-swimming cetacean. The rudimentary eye lacks the lens, but anatomical evidence suggests that the eye may serve as a light sensor. The underwater sound emissions of this species, although similar to those of the Amazon River dolphin (Inia geoffrensis), appear to be produced constantly.

As part of a study of the only river dolphin long recognized by native peoples as "blind" (Platanista gangetica), E. S. Herald, R. L. Brownell, Jr., F. L. Frye, and E. J. Morris spent 11 days on the Indus River near Sukkur, $515 \mathrm{~km}$ north of Karachi, West Pakistan (November 1968). We found that the blind dolphin has a variety of native names, the most common of which are buhlaan (West Pakistan) and susu (India).

The river dolphin family, Platanistidae, contains only four species; all are long-snouted and similar in appearance. The least known species occurs in Tung Ting Lake, China (Lipotes vexillifer). Another is widely distributed in the Amazon and Orinoco basins (Inia
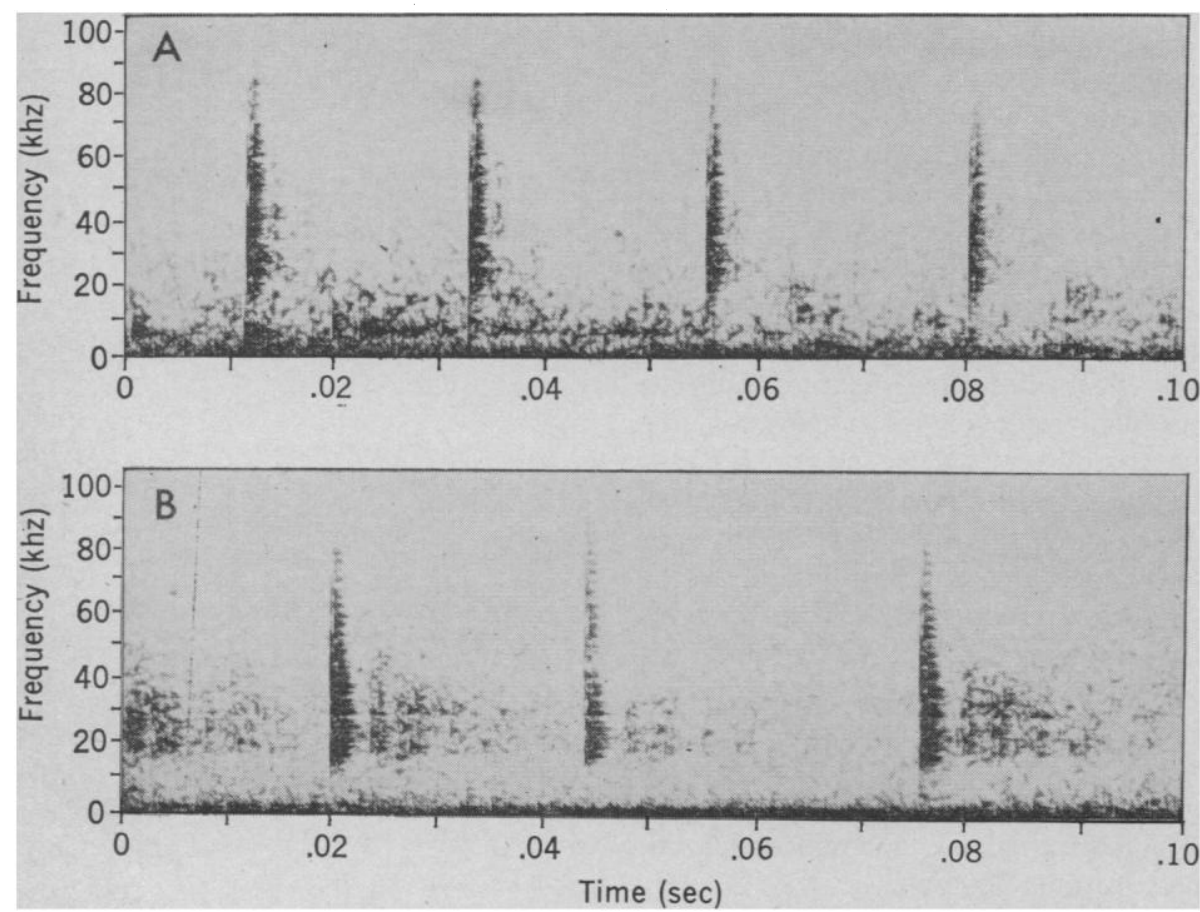

Fig. 1. Pulse trains produced by Inia geoffrensis (A) and Platanista gangetica (B). The ambient sound pressures in aquariums varied from 10 to $15 \mathrm{db}$ referred to $1 \mu \mathrm{bar}$. The animals were oriented with their rostrums pointed directly at the hydrophone at a distance of approximately $1 \mathrm{~m}$ (filter bandwidth, $480 \mathrm{hz}$ ).

geoffrensis), and the third occurs in the La Plata area (Pontoporia blainvillei). All three of these species have small eyes and apparently effective vision. Such is certainly true of the Amazon species which has recently become a public aquarium favorite. The fourth species, the blind river dolphin, is limited to the muddy waters of the Ganges, Indus, and Brahmaputra river systems. Its vestial eye is usually not visible externally, and its concealed location is shown only by a small opening in the skin usually smaller than that of the auditory meatus. Our anatomical studies have shown that the animal is not totally blind.

We obtained the dolphins from Sindi fishermen who use them for food. They are captured at night with a throw net, and a living catfish is used for bait. Three young females were taken: No. 1 on 4 November (total length, $121 \mathrm{~cm}$; $25.7 \mathrm{~kg}$ ); No. 2 on 7 November (115 $\mathrm{cm} ; 21.2 \mathrm{~kg}$ ); and No. 3 on 8 November $(107 \mathrm{~cm} ; 19.5 \mathrm{~kg})$. With the exception of abrasions on the lower jaw due to capture and subsequent tethering, the dolphins were remarkably free of injuries; even scratch marks were absent. in our holding pond on the Indus River, after surface breathing or blowing they started to roll the body as they swam
.

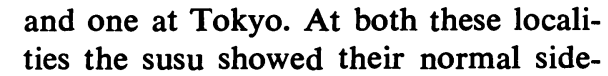
swimming pattern. Although they were continually presented with a wide variety of living and dead food, they would accept none. Consequently they were placed on a force-feed schedule.

In 1878, Anderson showed that Platanista lacked the crystalline lens of the eye (1). Our dolphins showed no reaction to drastic changes in light intensity, even when the initial intensity was at low illumination levels where rod activity would be seen. However, our anatomical study shows that the eye may be capable of serving as a light receptor, even if it is incapable of forming a clear image on the retina because of the flat shape of the cornea and the absence of an effective lens, with degeneration and absorption of the lens fiber. The retina is adapted to light-gathering rather than image-resolving, with a very densely packed receptor layer, a rather scanty bipolar and ganglion cell layer, and an extremely small optic nerve containing only a few hun- 
dred fibers; the pigment epithelium layer, which prevents light scatter within the eye itself, is absent. Because of the dense pigmentation of the overlying skin, light can reach the retina only through the pinhole sphincter-like lid structure. A cone-shaped muscle layer extends from the posterior orbit to the circumference of the skin overlying the eye, and its contraction would clearly open this sphincter; a definite circular sphincter-like arrangement of muscle fibers in the tissue certainly is the anatomical substrate for closure. Thus, the structure is present for sensing light and, maybe, even for telling its direction. Possibly the creature does use vision at night or at a seasonal migration or breeding time, although no utility is seen for vision in the muddy habitat where Platanista is usually found.

Echolocation in cetacea has been experimentally validated in only two species, Tursiops truncatus and Phocoena phocoena (2). However, every species of odontoceti studied thus far produces trains of clicks similar in many ways to those used by species known to echolocate (3). The blind river dolphin can now be added to this list. While the dolphins were in captivity at the Steinhart Aquarium, we monitored and recorded the sound emissions of all three Platanista as a group and of each individually, using a hydrophone (Chesapeake model CH26B), a matched high-gain amplifier system, and an instrumentation tape recorder (Lockheed model 417). The frequency response of the entire system at a tape speed of $30 \mathrm{inch} / \mathrm{sec}$ was flat $( \pm 3 \mathrm{db}$ from $100 \mathrm{hz}$ to $100 \mathrm{khz}$ ).

The underwater sounds of the Platanista consisted of trains of pulses which were produced constantly during the sound-monitoring periods. The pulses were produced at a rate of 20 to 50 per second. The amplitude of the pulses was strongly dependent on the animals' orientation with respect to the hydrophone. When the dolphins were swimming toward the hydrophone, the amplitude of the emitted signal would drop by 8 to $10 \mathrm{db}$ as the animal's rostrum would swing $10^{\circ}$ on either side of the transducer. When the orientation of the rostrum was more than $40^{\circ}$ away from the hydrophone, the signal level was reduced by 15 to $20 \mathrm{db}$. During the entire 16 hours of monitoring, there were no periods in which pulse trains were not observed. Variation in light intensity and the

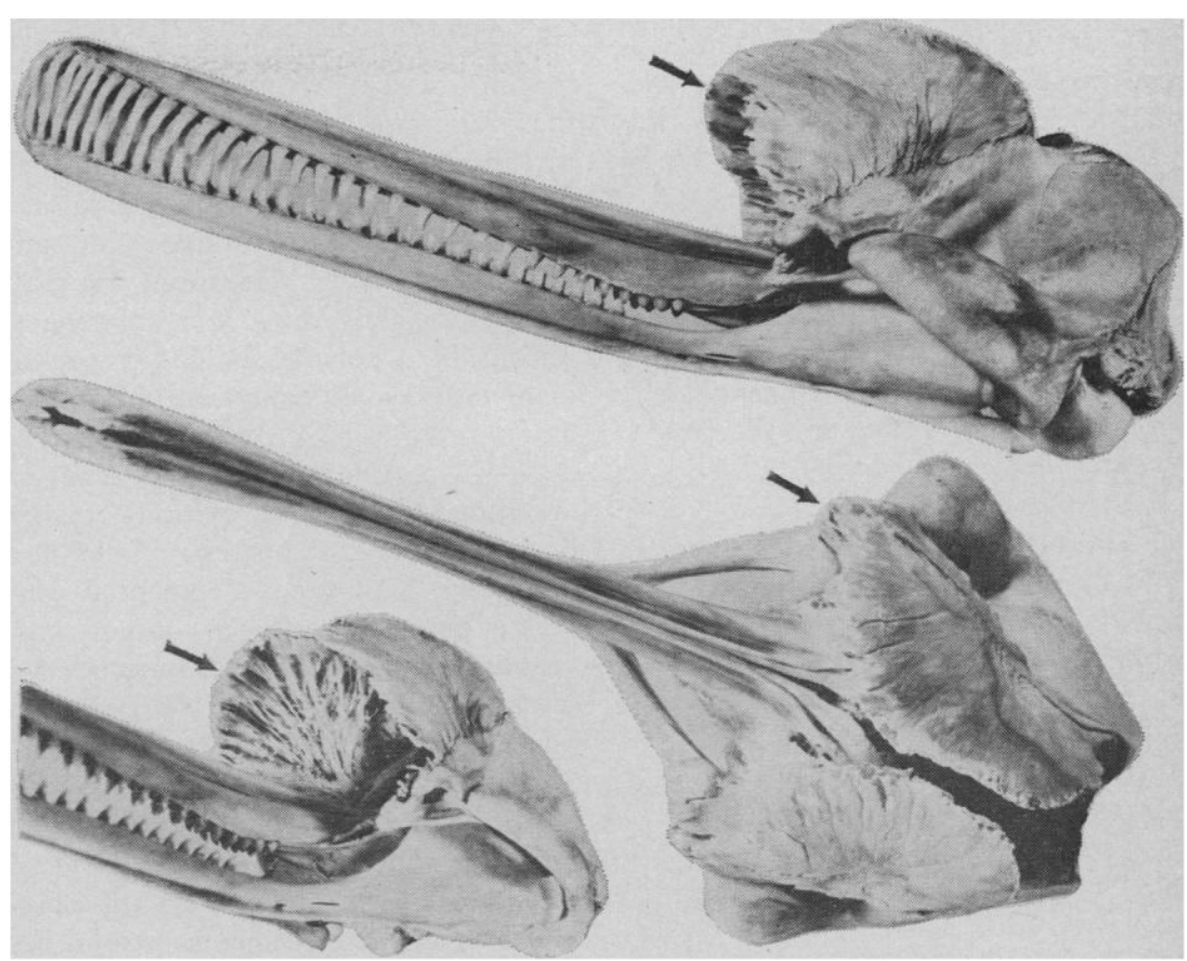

Fig. 2. Lateral, dorsal, and antero-oblique views of the skull of Platanista gangetica, showing the nature of the maxillary extensions (arrow).

presence of objects in the tank, for example, hydrophone or wood or pipe barriers, did not appear to influence the animal's sound emissions.

By contrast, the related Amazon dolphins, Inia geoffrensis, in an adjacent tank produced trains of pulses only during orientation toward food or strange objects, or both, placed in their tank. The pulse trains produced in these cases were similar in amplitude, repetition rate, and dependency on orientation to those emitted by Platanista. However, when the light intensity was reduced, Inia responded by more frequent sound emissions.

The wave form and frequency content of individual pulses produced by both Platanista and Inia are quite similar, with maximum energy between 15 and $60 \mathrm{khz}$ (Fig. 1). The pulses produced by both of these freshwater odontoceti have considerably less energy below $15 \mathrm{khz}$ than has been observed in most other delphinids. This could partially account for the observation reported by Norris (2) that Inia produce low-intensity signals. Most previous recordings of pulses produced by Inia have been made on systems with limited frequency response, that is, $50 \mathrm{hz}$ to $20 \mathrm{khz}$. Unfortunately, the short time available for acoustic observation of this unique cetacean did not allow for any definitive test of echolocation capability. The degenerate nature of the eye, constant pulse emission, and obstacle-avoidance behavior, both in the natural murky habitat of the dolphin and in captivity, suggest that Platanista is an effective echolocator.

Among cetaceans, the blind river dolphin has a unique skull in that there are broad maxillary flanges which extend upward into the forehead melon (Fig. 2). These paired flanges do not meet in the center dorsally, thus leaving a variable gap of about 5 to $10 \mathrm{~mm}$ (21.2-kg female). Although the outside of each flange is smooth, the inside supporting structure has a very intricate, radial, weblike appearance. Based upon the work of Evans et al. (4), which indicates that the topography of the delphinid skull has an effect on the sound field, we suspect that the Platanista maxillary flanges act as acoustic baffles to direct the sonic pulses into a narrow beam.

From the time of capture, blind dolphin No. 1 survived for 38 days, No. 2 for 24 days, and No. 3 for 44 days. Primary cause of death for the two larger animals was pneumonic infection; for the smallest dolphin the injury to the lower jaw at the time of capture was deemed responsible; other factors may also have been involved.

The three complete skeletons that have been prepared are the first from 
the Indus River; the two larger skeletons are located at the California Academy of Sciences (CAS 14921 and 14922), and the smallest is at the Museum of Comparative Zoology (MCZ 52306).

EARL S. Herald

RoBERT L. BROWNELL, JR.

Fredric L. Frye, ElKan J. Morris

Steinhart Aquarium, California

Academy of Sciences, San Francisco

William E. Evans

Naval Undersea Research

and Development Center,

San Diego, California 92132

Alan B. ScotT

Institute of Medical Sciences,

Pacific Medical C'enter,

San Francisco, California 94115

References and Notes

1. J. Anderson, Anatomical and Zoological Researches: Comprising an Account of the Zoological Results of the Two Expeditions to Western Yunnan in 1868 and 1875 (Quaritch, London, 1878), vol. 1, pp. 417-550; vol. 2 , pp. $25-26,28-32,34-41$

2. K. S. Norris, in The Biology of Marine Mammals, H. T. Anderson, Ed. (Academic Press, New York, 1969), pp. 393-400, 416-417.
3. W. E. Evans, in Marine Bio-Acoustics, W. N. Tavolga, Ed. (Pergamon, Oxford, 1967), vol. 2 , pp. 159-186.

4. W. E. Evans, W. W. Sutherland, R. G. Beil, in Marine Bio-Acoustics, W. N. Tavolga, Ed. Marine Bio-Acoustics, W. N. Tavolga, Ed.
(Pergamon, Oxford, 1964), vol. 1, pp. 353-372.

1 April 1969; revised 16 September 1969 